\title{
Jobsheet Learning Media Development of Stone and Concrete Working Practice Courses Building Engineering Education Program of Padang State University
}

\author{
Wahyu Hutria1, Nurhasan Syah ${ }^{2}$, Azwar Inra ${ }^{3}$ \\ ${ }^{1}$ Pendidikan Teknologi Kejuruan, Fakultas Teknik, Universitas Negeri Padang \\ 2Jurusan Teknik Sipil, Fakultas Teknik, Universitas Negeri Padang \\ ayuhutria@gmail.com,nurhasan s@yahoo.com, azwar inra52@yahoo.co.id
}

\begin{tabular}{ll}
\hline Article History & Received : January $7^{\text {th }} 2021$ \\
& Revision : February $11^{\text {th }} 2021$ \\
& Publication : March $30^{\text {th }} 2021$ \\
\hline
\end{tabular}

\begin{abstract}
Jobsheet learning media is designed to improve student learning outcomes so that students can understand the overall material provided and help learn independently. This research aims to develop a Jobsheet learning medium in the course of Stone and Concrete Work Practices Building Engineering Education Study Program that is valid, practical, and effective. This research uses Research and Development ( $R \& D)$ method with 4-D development model. The subject of the study was a building engineering education student who took a course in Working Practice of Stone and Concrete Semester January-June 2019. The results obtained in this study are as follows:(1) produce jobsheet learning media (2) Validity of Jobsheet learning media, declared valid on the content aspect with a value of 0.83 and valid on the aspect of media format with a value of 0.89 , (3) Practicality of jobsheet learning media based on two responses lecturers expressed very practical with a percentage of $89.92 \%$ and based on 15 responses students expressed very practical with a percentage of $85.03 \%$, (4) Jobsheet learning media, otherwise effective can improve the knowledge aspect of students who use Jobsheet seen from student learning outcomes and effectively improve aspects of student skills seen from results and practice reports. Based on the results of this study, it can be concluded that jobsheet learning media has been valid, practical and effective as a teaching material in the course of Working Practice of Stone and Concrete.
\end{abstract}

Keywords: Learning Media, Jobsheet, R\&D

\section{INTRODUCTION}

Education plays an important role to improve the quality of human resources and efforts to achieve the ideals of the Indonesian nation so as to create a smart and welfare nation in society. The quality of human resources greatly affects the 
progress of a nation, so it can indirectly be said that education will determine the quality of a nation.

Universitas Negeri Padang (UNP) is one of the State Universities that has implemented the quality standards of ISO 9001: 2000 management. This gives an idea that UNP is a higher education provider with highly qualified quality management. The relationship between education and the quality of graduates, can be seen from the output or graduates, and qualified human resources are formed if the process of education carried out is also qualified.

Faculty of Engineering UNP, especially in the study program Building Engineering Education wants to create students or graduates who can compete in the world of work to achieve this, the Study Program must have the necessary learning achievements in the world of education, industry and companies. The needs of the world of work that expects the understanding of the implementation of the stages of work make each practice course requires the existence of learning media, one of which is the course Of Working Practice Stone and Concrete.

Active learning requires lecturers to develop and innovate in order to help students in the learning process. However, in the learning process Of Stone and Concrete Working Practices are still experiencing problems such as materials for each work item studied requires visualization to understand the concept of learning. Lecturers can take advantage of the development of science and technology to develop learning aids. Tools can be learning media that can visualize materials and can attract students. The need for detailed work drawings and mathematical analysis of the planning materials used contributes more to students understanding learning achievements.

Presurvey that has been done during the lecture Of Stone and Concrete Work Practice, some students revealed that they do not utilize the existing jobsheet as it should and its usefulness. The situation will certainly affect the student's understanding of the lecture materials that will be studied because the jobsheet is very helpful for students to start work and how the next step of work. The number of mistakes in the planning of the practice done by students as well as the calculation of materials needed also often occur during learning. In line with that, students also mention that they are often confused to start work not even know what to do first.

The evaluation aspect listed in the jobsheet shows a learning evaluation that does not focus on measuring the learning achievements performed by students whenever they finish doing work items. Similarly, the implementation of the evaluation emphasizes the final results of the work, has not focused on measuring attitudes and skills. This condition has the potential to produce graduates who are not in accordance with the expected learning achievements.

The following is the percentage of learning results of Stone and Concrete Working Practices of students of Building Engineering Education Study Program. 
Table 1. Percentage of Learning Results of Stone and Concrete Working Practices of Students of Building Engineering Education Study Program in 2017-

2018

\begin{tabular}{|c|c|l|l|l|l|l|}
\hline \multirow{2}{*}{$\begin{array}{c}\text { School } \\
\text { Year }\end{array}$} & Number of & \multicolumn{5}{|c|}{ Number / Percentage of Student Grades } \\
\cline { 3 - 7 } & Students & \multicolumn{1}{|c|}{$\mathrm{A}$} & \multicolumn{1}{|c|}{ A- } & \multicolumn{1}{c|}{ B+ } & \multicolumn{1}{c|}{ B } & \multicolumn{1}{c|}{$<=$ B- } \\
\hline \multirow{2}{*}{2017} & \multirow{2}{*}{26} & 1 & 14 & 8 & 0 & 3 \\
\cline { 3 - 7 } & & $3,85 \%$ & $53,85 \%$ & $30,77 \%$ & $0,00 \%$ & $11,54 \%$ \\
\hline \multirow{2}{*}{2018} & \multirow{2}{*}{32} & 0 & 21 & 10 & 0 & 1 \\
\cline { 3 - 7 } & & $0,00 \%$ & $65,63 \%$ & $31,25 \%$ & $0,00 \%$ & $3,13 \%$ \\
\hline
\end{tabular}

Source : Documentation of Lecturers of Stone and Concrete Working Practices

Learning results on Tabel 1. it can be said that the implementation of the learning process of Stone and Concrete Working Practices has not run optimally because there are still many students who have not been able to obtain better learning outcomes, even though the standard of completion has been met. In practical courses learning achievements are not only oriented on aspects of knowledge, but also skills.

To overcome the above problems, a solution was chosen, namely to develop jobsheet learning media as teaching materials in the implementation of stone and concrete work practice learning. It is expected that with the use of this learning media students who are usually confused starting each work item can play a more active and ready role, not hesitate at the time the practice will begin. The learning of practical courses is closely related to activities that carry out a series of practical activities (work steps). To support this, learning needs to be equipped with jobsheetlearningmedia.

According to Hisham et al (2002:4) in planning and delivering lecture materials to students, there are several factors that must be considered by educators or lecturers, namely students, study rooms, methods to be used, and the learning materials themselves. Students who are the subject of learning then students should get more attention in every learningprocess.

The curriculum of The Undergraduate Study Program (S1) of Building Engineering Education unp developed based on the description of the vision, mission and objectives of the study program that also refers to the vision and mission of the Faculty of Engineering and State University of Padang. Working Practice of Stone and Concrete is one of the courses that must be taken by students of building engineering education program oriented to skills.

Sadiman (2011:7) revealed that learning media is something that can be used and used to convey messages from the sender to the recipient so as to stimulate the mind, and the feelings, interests and attention of students so that the learning process occurs. Sanjaya (2012:61) also revealed that learning media is everything 
like a tool or environment with all forms of activities that can be conditioned to increase knowledge, instill attitudes and improve skills in everyone. Sudjana (2013:2) said that in the process of learning the use of learning media has the following benefits (a) Teaching will attract more students, so as to foster learning motivation; (b) The subject matter is clearer so that it is easily understood by the learners; and (c) Teaching methods will vary more.

Developmentis a process or effort that is done consciously, planned to make a new product or improve an existing one, so that it becomes a product or result that will benefit the public to improve the quality and better quality that has been tested feasibility. Sugiyono (2014:5) describes "development is deepening and expanding existing knowledge".

Suyono (Aryadi et al. 2011: 69) said jobsheet is a book written that aims to allow students to learn independently without or with the guidance of teachers. Trianto (2011:222) also revealed"jobsheets or student worksheets are student guides used to conduct investigation or problem solving activities". Based on the description of the definition of jobsheet above can be interpreted that jobsheet is a practice procedure of a job in the form of a sheet covering the purpose of practice, and assignment so that students can study independently with or without the guidance of lecturers. 


\section{METHOD}

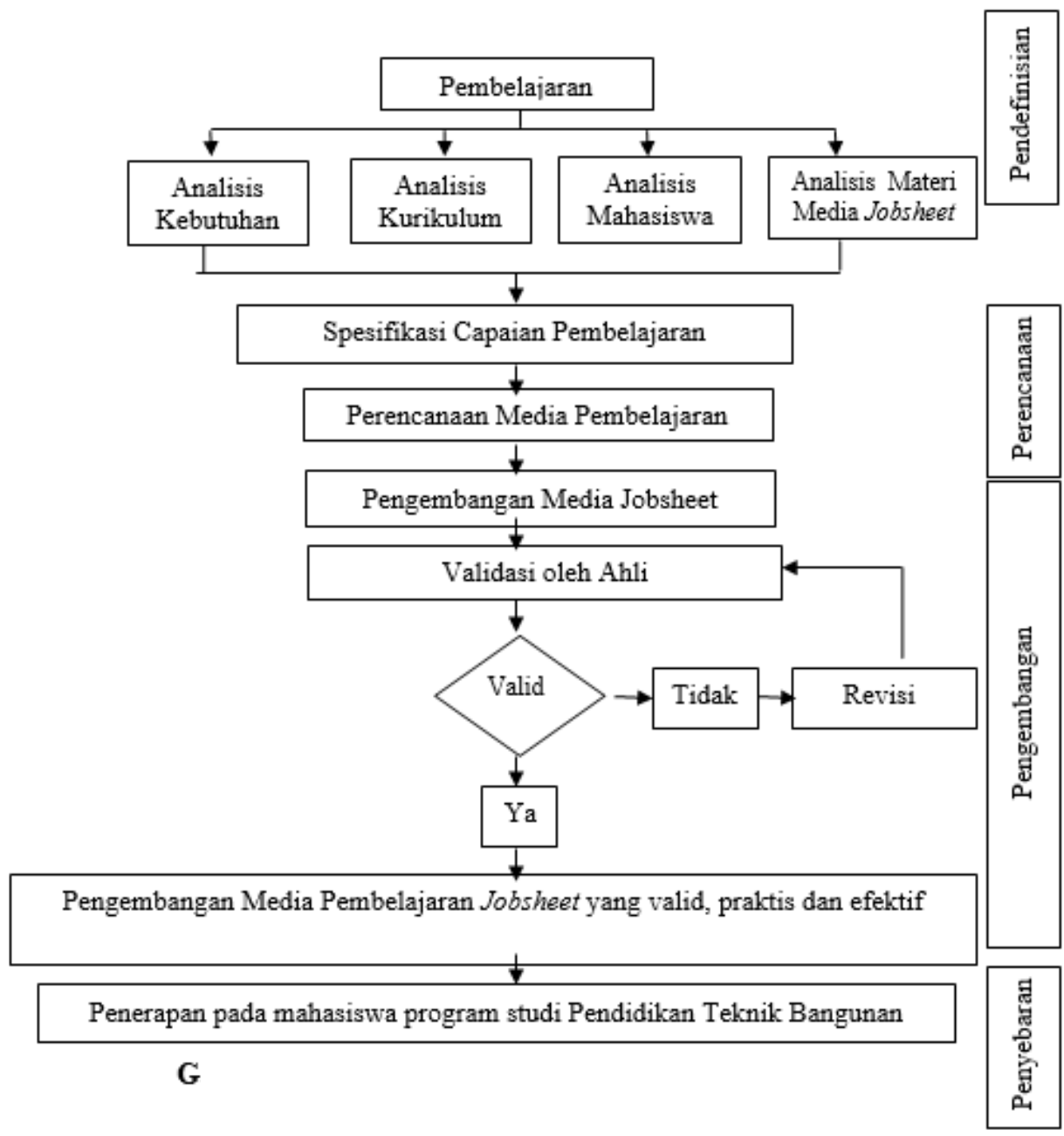

Figure 1. Four-D Model Development Research Procedure

This research uses a 4-D development model (four D) that is research that has simple, systematic, and detailed procedures covering all aspects that must be analyzed so that the right 4-D model is used to develop learning devices. The jobsheet development research procedure uses modified 4-D models. This development model consists of four stages namely Define (definition), this stage is a needs analysis in which the analysis of lecture conditions that occur before the development so as to obtain solutions and selection of media development or teaching materials that are appropriate to the needs in the lecture process, Design (design), develop improve the existing jobsheet by redesigning the jobsheet according to the needs., Develop (development) that will be implemented consists of 3 actions, namely, validation stage, practicality and effectiveness of jobsheet. Disseminate (dissemination) is done by introducing jobsheet products for use by anyone both individuals and groups. 
The type of data is secondary data obtained from observations, curriculum analysis, and student data while primary data is obtained from validation results from experts, practical test results based on the response of lecturers and students and effectiveness test results from the results of learning knowledge and skills of students.

The data collection instruments used in this study are: (1) Validity Sheet Instruments, (2) Practical questionnaire instruments,(3) Effectiveness sheet instruments aspects of knowledge and skills.

Data analysis techniques used in this study are descriptive data analysis techniques, namely by describing the validity, practicality, and effectiveness of the use of jobsheets in the courses of Stone and Concrete Work Practices building engineering education program as follows:

Analysis of validity with Aiken's $\mathrm{V}$ formula

$$
V: \sum s /[n(c-1)]
$$

Practicality Analysis with formulas:

$$
N A: \frac{S}{M} \times 100 \%
$$

Effectiveness analysis is:

a. Aspects of Knowledge

$$
g=\frac{\text { Spostest }- \text { Spretest }}{\text { Smaksimum-Spretest }}
$$

b. Skill Aspects

$$
\text { Tingkat pencapaian }=\frac{\sum \text { skor yang diperoleh }}{\sum \text { skor maksimum }} \times 100 \%
$$

\section{RESULTS AND DISCUSSION}

This research resulted in a jobsheet in the course Of Working Practice of Stone and Concrete. The resulting jobsheet details are composed of components. The component consists of learning outcome,material / short theory, equipment tools and materials, work safety, work steps, task description, assessment description and reference.

This research is through the stages of development, namely
a. Definition(needs
analysis,
curriculum/syllabus
analysis,
studentcharacteristicsanalysis, and material analysis),
b. Design stage (jobsheet media creation), 


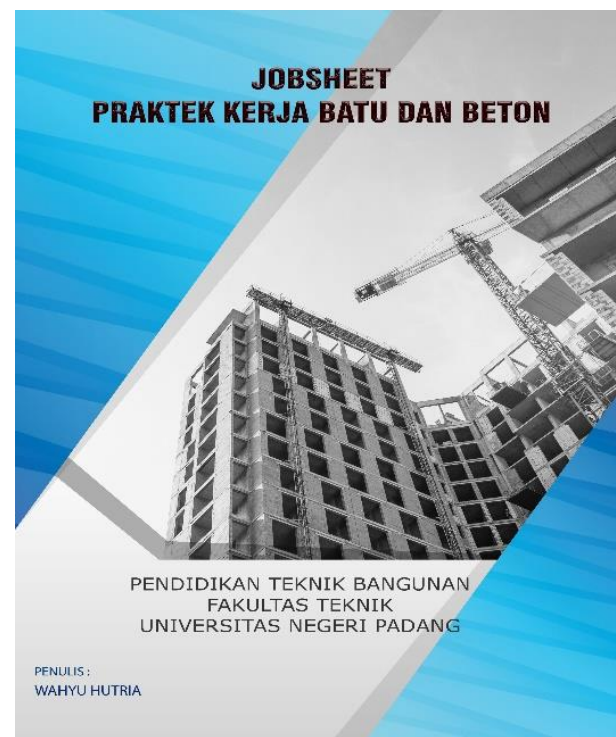

Figure 2. Cover/ Cover Jobsheet

c. Tahap development

Validity test data with Aiken's V:

Table 2. Content Validator Rating

\begin{tabular}{|c|l|c|c|}
\hline No & Indicator & Aiken's V & Category \\
\hline 1 & Content Aspects & 0,85 & Valid \\
\hline 2 & Learning Aspects & 0,83 & Valid \\
\hline 3 & Display Aspects & 0,80 & Valid \\
\hline \multicolumn{2}{r|}{ Amount } & 0,83 & Valid \\
\hline
\end{tabular}

Validity test result obtained $0.83>0.667$ categorized as valid.

Table 3. Validator Assessment of Media Formats

\begin{tabular}{|c|l|c|c|}
\hline No & Indicator & Aiken's V & Ket \\
\hline 1 & Content Aspects & 0,88 & Valid \\
\hline 2 & Language Aspects & 0,91 & Valid \\
\hline 3 & Media Aspects & 0.89 & Valid \\
\hline \multicolumn{2}{|c|}{ Amount } & 0,89 & Valid \\
\hline
\end{tabular}

Validity test results obtained $0.89>0.667$ categorized as valid. 
Practicality test data :

Table 4. Practicality Test Results

\begin{tabular}{|l|l|c|c|}
\hline No & Praktikalitas Media Jobsheet & Percentage & Category \\
\hline 1. & Results of lecturer practicality & $89,29 \%$ & Very Practical \\
\hline 2. & Student practicality results & $85,03 \%$ & Very Practical \\
\hline
\end{tabular}

Based on the response of lecturers through practicality questionnaire obtained the percentage of assessment of both lecturers obtained an average of 89.29\% then jobsheet courses Of Working Practice Stone and Concrete can be categorized "verypractical". Based on the response of students through the questionnaire obtained the percentage of average value of $85.03 \%$ so that it can be concluded jobsheet of The Work Practice of Stone and Concrete courses entered in the "category is verypractical"

Effectiveness test data :

Aspects of Knowledge :

Table 4. Practicality Test Results

\begin{tabular}{|c|c|c|}
\hline Class & Experiment Class & Control Class \\
\hline Spre & 33,07 & 32,00 \\
\hline Spost & 80,27 & 72,27 \\
\hline Gain & 0,71 & 0,59 \\
\hline Description & High & Are \\
\hline
\end{tabular}

The results of the analysis obtained a gain of 0.71 . This means that experimental classes have improved learning outcomes in high categories because $\mathrm{g} \geq 0,7$. In the ontrol class earned a 382pretest average of 32.00 and a posttest average of 72.27. So obtained a gain of 0.59 . This means that 382 ontrol classes also experience an increase in learning outcomes, but the increase is in the moderate category due to $0.7>\mathrm{g} \geq 0.3$.

Skill Aspects : 


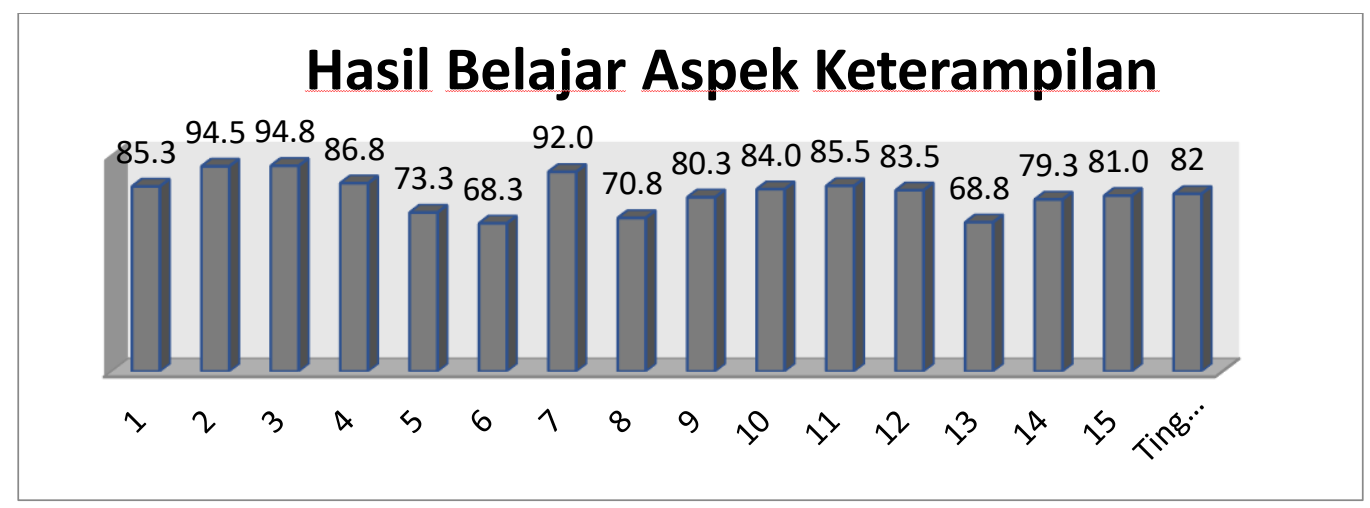

Figure 3. Student Skills Value Histogram

Based on the results of student practice value obtained achievement level of $82 \%$ in the category is very effective then it can be concluded that the use of media jobsheet courses Practical Work Stone and Concrete effectively improve skills (softskill) students.

The advantage of jobsheet developed is that it is easily accessible independently both in the form of books and files, in addition it can lead students to create tasks and work reports that have been done. The development of jobsheet media courses Of Stone and Concrete Working Practices is done by looking at the development of jobsheet researchers terdahulu. Jobsheets are simple, concise, but can make it easier for students to practice. So that students in carrying out the practice can be achieved to the maximum, without having to ask the lecturers too often. Because with the jobsheet it includes all what students have to do in carrying out the practice. This will highlight the creativity of students such as analyzing the material needs for each work item according to the work picture. The assessment description on the jobsheet developed is equipped with an assessment rubric that is used as a guideline to assess aspects of students' skills and attitudes at the time of carrying out the work.

Judging from the content aspect of the jobsheet content material, the validator states that the learning media of the Stone and Concrete Working Practice jobsheet developed as one of the learning materials is in accordance with the curriculum, and learning outcomes that must be achieved by students, including the suitability of jobsheet content, clarity of instructions, preparation of materials, conformity between the materials practiced with the learning media, the suitability of images with the materials practiced, the display of images and writings so as to make it easier for students to understand the learning materials. The value of content validation content learning media learning jobsheet courses Practice Work Stone and Concrete developed is 0.83 with a valid category. Content validation is a condition related to the process of finding the correct concepts and in accordance with the applicable curriculum. Valid validation results for content validation indicates that the jobsheet learning media of The Stone and Concrete Working 
Practice course developed has been very in accordance with the curriculum used today.

In the mediaformataspect, the validation value of the validator also obtains a valid value that is 0.89 is categorized as valid. The validity of the jobsheet format is the suitability of the jobsheet components with the predefined elements. Based on the validity value obtained from the validator, it can be concluded that the jobsheet learning media of The Stone and Concrete Working Practice course developed has been in accordance with the requirements of jobsheet learning media construction.

The practicality test of jobsheet learning media of Stone and Concrete Working Practice courses is conducted by lecturers and students through questionnaires of lecturers and students' responses. Jobsheet practicality test results by lecturers obtained an average percentage of 89.29 in the very practical category. These results show that the media jobsheet of The Stone and Concrete Working Practice Course developed makes it easier for lecturers in helping students learn independently and helping lecturers provide the concept of learning materials to students. Practicality of learning media jobsheet Work Practice Stone and Concrete based on student response with an average value percentage of 85.03 with a very practical category. The results of this pratikalitas test show that the jobsheet developed can make it easier for students to understand the material.

To test the differences in the significance of the learning outcomes of the control class and the experimental class using the Gain score test. Based on the data, obtained a gain of 0.71in the experimental class means an increase in the results of learning experimental classes in the category is high because $g \geq 0,7$. In the control class gained a gain of 0.59 , meaning the control class also experienced an increase in learning outcomes, but the increase in the moderate category due to 0.7 $>g \geq 0.3$. The results of the analysis test showed that the use of jobsheet media is very good for improving the learning outcomes of students of Batu and Beton Working Practice courses compared to the learning outcomes of students who do not use jobsheet learning media. So, it can be concluded that learning by using jobsheets can be said to be effective in improving student learning outcomes.

In addition to effectively improving student learning outcomes, thelearning media jobsheet of Stone and concrete valid Working Practice courses effectively also improves students' skills. From the results of the assessment of student skills sheets during practice and completing the practice report, an average score of $82 \%$ was obtained in the highly effective category. This proves the use of jobsheet learning media assistance of Stone and Concrete Working Practice courses can help students improve softskill (skills) in applying the concept of learning that they understand.

\section{CONCLUSION}


Development research produces a jobsheet learning media courses Work Practices Stone and Concrete valid, practical and effective in Building Engineering Education Faculty of Engineering Padang State University with a 4-D development model. Research on the development of jobsheet learning media results in a test of the validity of jobsheet learning media that has fulfilled the content aspect, with an average of 0.83 categorized as valid, and the format aspect obtained with an average of 0.89 categorized as valid, can be concluded jobsheet learning media courses Stone and Concrete Practice developed is valid to be used as a learning medium in the learning process. In practicality tests the media can be used in its entirety well. This can be seen from the results of lecturer responses with an average of $89.92 \%$ in the very practical category and student response results by obtaining an average of $85.03 \%$ in the very practical category, these results show the jobsheet developed falls into the category of very practical use by lecturers and students. And test the effectiveness of the media developed judging from the results of students who use jobsheets better than the results of students who do not use jobsheets, and shows that there are differences in learning outcomes from the aspects of knowledge and aspects of skills and the effectiveness of the use of jobsheet media Practice Stone and Concrete. So that the learning media jobsheet has been declared valid, practical and effective to improve the knowledge aspect and the skills aspect of students.

For lecturers can use the learning media jobsheet Work Practice Stone and Concrete as a media supporting the learning process because it effectively improves aspects of knowledge and aspects of skills in each material contained in the media jobsheet developed. For students to be able to use the learning media jobsheet Work Practice Stone and Concrete because it can improve the understanding of learning concepts, creative thinking in solving problems so as to encourage themselves to improve learning outcomes. It is recommended to other researchers to be able to develop jobsheet learning media on other courses or other campuses because it effectively improves students' knowledge and skills. In addition, it is expected that other researchers can develop more interesting jobsheet learning media

\section{Author Biodata}

Wahyu Hutria, born August 17, 1991 in Payakumbuh, West Sumatra. Bachelor of Building Engineering Education majoring in Civil Engineering, Faculty of Engineering, State University of Padang 2014. Currently a Postgraduate master's program in technology and vocational education program, Faculty of Engineering, State University of Padang.

Dr. Nurhasan Syah, MPd, born November 5, 1960 in Bukittinggi, West Sumatra, he is a lecturer in the department of Civil Engineering, he is also a lecturer in the Master program of Vocational Technology Education, Faculty of Engineering, State University of Padang. 
Dr. Azwar Inra, MPd, born August 22, 1952 in Tapanuli Selatan, North Sumatra, he is a lecturer in the department of Civil Engineering, he is also a lecturer in the Master program of Vocational Technology Education, Faculty of Engineering, State University of Padang.

\section{REFERENCES}

Adnyawati, Ni Desak Made Sri. (2004). Peningkatan Keterampilan Proses dan Hasil Pembelajaran Dekorasi Kue Melalui Metode Demonstrasi dan Media Job Sheet Mahasiswa Jurusan PKK IKIP Negeri Singaraja. Jurnal Pendidikan dan Pengajaran IKIP Negeri Singaraja (No 1 Tahun XXXVII). Hlm. 154-166.

Aryadi, Widya, dkk. (2011). Peningkatan Hasil Belajar Melalui Penerapan Media Pembelajaran Jobsheet Pada Panel Peraga Sistem Kelistrikan Otomotif. Jurnal Pendidikan Teknik Mesin. Vol. 11. No. 2. Hal. 68-71.

Hisyam, Zaini, dkk. (2002). Desain Pembelajaran di Perguruan Tinggi. Yogyakarta: IAIN Sunan Kalijaga.

Sadiman, Arif S. R. Rahardjo, Anung Haryono, dan Rahardjito. (2012). Media Pendidikan (Pengertian, Pengembangan, dan Pemanfaatannya). Depok: Raja Wali Press.

Sanjaya, Wina. (2012). Media Komunikasi Pembelajaran. Jakarta: Kencana.

Sudjana, Nana dan Rivai, Ahmad. (2007). Teknologi Pengajaran. Bandung: CV. Alfabeta.

Sugiyono. (2014). Skripsi, Tesis dan Disertasi. Bandung: Alfabeta.

Tim Pengajar. (2012). Perangkat Pembelajaran Praktek Kerja Batu dan Beton. Padang. Teknik Sipil UNP.

Tim Penyusun. (2015). Pedoman Penyusunan Tesis dan Disertasi Program Pascasarjana Fakultas Teknik Universitas Negeri Padang. Padang. FT UNP.

Trianto. (2011). Mendesain Model Pembelajaran Inovatif Progresif. Jakarta: Kencana Prenada Media Group. 